Article

\title{
Spirulina Platensis Supplementation Coupled to Strength Exercise Improves Redox Balance and Reduces Intestinal Contractile Reactivity in Rat Ileum
}

\author{
Layanne C. C. Araujo ${ }^{1}$ (D) Aline F. Brito ${ }^{2}$, Iara L. L. Souza ${ }^{3}$, Paula B. Ferreira ${ }^{3}$, \\ Luiz Henrique C. Vasconcelos ${ }^{3}\left(\mathbb{D}\right.$, Alexandre S. Silva ${ }^{4}$ id and Bagnólia A. Silva ${ }^{1,3,5, *}$ \\ 1 Programa de Pós-graduação em Ciências (Fisiologia Humana), Instituto de Ciências Biológicas, \\ Universidade de São Paulo, Sao Paulo/SP 05508900, Brazil; lay_bomed@yahoo.com.br \\ 2 Escola de Educação Física, Universidade de Pernambuco, Recife/PE 50740-465, Brazil; \\ alineebritoo@gmail.com \\ 3 Programa de Pós-graduação em Produtos Naturais e Sintéticos Bioativos, Centro de Ciências da Saúde, \\ Universidade Federal da Paraíba, Joao Pessoa/PB, 58051900, Brazil; iara-04@hotmail.com (I.L.L.S.); \\ paulabenvindo92@hotmail.com (P.B.F.); Henrique.luiz89@gmail.com (L.H.C.V.) \\ 4 Departamento de Educação Física, Centro de Ciências da Saúde, Universidade Federal da Paraíba, Joao \\ Pessoa/PB 58051900, Brazil; alexandresergiosilva@yahoo.com.br \\ 5 Departamento de Ciências Farmacêuticas, Centro de Ciências da Saúde, Universidade Federal da Paraíba, \\ Joao Pessoa/PB 58051900, Brazil \\ * Correspondence: bagnolia@ltf.ufpb.br
}

Received: 11 November 2019; Accepted: 27 December 2019; Published: 29 January 2020 updates

\begin{abstract}
The blue alga Spirulina platensis has presented several pharmacological activities, highlighting its actions as an anti-inflammatory and antioxidant. In addition, there are few studies with the influence of strength training on physiological parameters, as intestinal contractility and oxidative cell damage. We evaluated the influence of S. platensis supplementation, strength training, and its association on contractile reactivity of rat ileum, as well as the balance of oxidative stress/antioxidant defenses. Methods: Male Wistar rats were divided into; sedentary (S); $\mathrm{S}+$ supplemented with algae at 50 (S50), 150 (S150), and 500 mg/kg (S500); trained (T); and T + supplemented (T50, T150, and T500). Contractile reactivity was analyzed by kymographs; oxidative stress on ileum by the malondialdehyde (MDA) formation; and the antioxidant capacity by 2,2-diphenyl-1-picrylhydrazyl (DPPH) method. S. platensis supplementation reduced the reactivity of rat ileum to carbachol (CCh) and $\mathrm{KCl}$, while training reduced only the $\mathrm{CCh}$ efficacy. In addition, association potentiated the reduction on contractile reactivity. Supplementation reduced the oxidative stress and increased oxidation inhibition; training alone did not alter this parameter, however association potentiated this beneficial effect. Therefore, this study demonstrated that both supplementation and its association with strength training promote beneficial effects regarding intestinal contractile reactivity and oxidative stress, providing new insights for intestinal disorders management.
\end{abstract}

Keywords: blue algae; Spirulina platensis; contractile reactivity; oxidative stress; ileum

\section{Introduction}

The use of natural products by humans comes from many years and science that has increasingly recognized its active action, including in modern pharmacotherapy with various drugs of vegetable origin $[1,2]$. Besides these products, there are those from aquatic origin, which, unlike the plants, are not commonly used in traditional medicine [3]. 
Despite this, several studies have reported the pharmacological importance of metabolites derived from aquatic products, such as chemotherapeutic, anti-inflammatory, hypoglycemic, and antioxidant activities [4-6]. In this way, aquatic bioactive products may be used as a therapeutic tool for many diseases, and therefore should be more studied for new discoveries in the field of pharmacology and therapeutics.

Some aquatic products have been already marketed and used as food supplements, such as the blue-green algae Spirulina platensis. It belongs to the Cyanobacterial phylum and the family Spirulinaceae [7] and has been widely used due its nutritional value. Furthermore, several studies have reported its importance for the treatment of cardiovascular, metabolic, and inflammatory diseases, in addition to its antioxidant properties [8-10]. Brito et al., 2018 [11] showed that chronic supplementation with $S$. platensis decreased contractile reactivity and increased relaxing activity. Also, it was shown that the factors that accompanied this improvement in reactivity involve the release of nitric oxide and reduction in oxidative stress and systemic inflammation. Accordingly, these data demonstrated for the first time that the synergistic action between strength training and S. platensis results in improving vascular reactivity.

Changes in intestinal contractility are responsible for several symptoms like colic, diarrhea, and constipation [12], and S. platensis has presented beneficial effects in gastrointestinal inflammatory diseases, such as colitis [13]. S. platensis was found to have beneficial effects in constipation, enhancing gut peristalsis, curing the inflammatory reaction in the chorionic villus, and modulating the composition of the intestinal microbiota of mice [14]. However, there is a lack of studies about the effect of this algae on the intestinal contractile reactivity.

Physical exercise has been recommended as a therapeutic tool for the prevention and treatment of diseases and disorders of the gastrointestinal tract. The acute and chronic aerobic swimming exercise modifies the contractile gastrointestinal reactivity, thus contributing to the improvement of these gastrointestinal symptoms $[15,16]$. However, nothing has been demonstrated about the influence of anaerobic exercise of resistance on intestinal contractility, and the effects of the combination of exercise and S. platensis supplementation.

Thus, based on the beneficial effects of $S$. platensis for health and the influence of physical exercise on organ and body systems functioning, the aim of this study was to evaluate the effect of S. platensis supplementation, strength exercise, and its combination, on the contractile reactivity of rat ileum.

\section{Results}

\subsection{Electromechanical Coupling Contractile Reactivity Measurement}

Cumulative concentration-response curves to $\mathrm{KCl}\left(10^{-3}\right.$ to $\left.3 \times 10^{-1} \mathrm{M}\right)(n=3-5)$ were attenuated, with reduction on $E_{\max }$ values, by the supplementation with $S$. platensis at the doses of 50,150, and $500 \mathrm{mg} / \mathrm{kg}$ compared to control $(p<0.05)$. The strength training did not modify the efficacy of $\mathrm{KCl}$ in relation to $S$; however, the supplementation of trained animals with the algae reduced the efficacy of $\mathrm{KCl}$ at doses of 50 and $150 \mathrm{mg} / \mathrm{kg}(p<0.05)$, compared to $S$, but not at $500 \mathrm{mg} / \mathrm{kg}$. Analysis of $\mathrm{pEC}_{50}$ values showed that the supplementation with the algae at $50 \mathrm{mg} / \mathrm{kg}$ increased the potency of $\mathrm{KCl}$ $(p<0.05)$, compared to $\mathrm{S}$; however, this was not observed at doses of 150 and $500 \mathrm{mg} / \mathrm{kg}$. In addition, the training or the association with the algae did not alter this parameter, compared to control group (Figure 1, Table 1). 

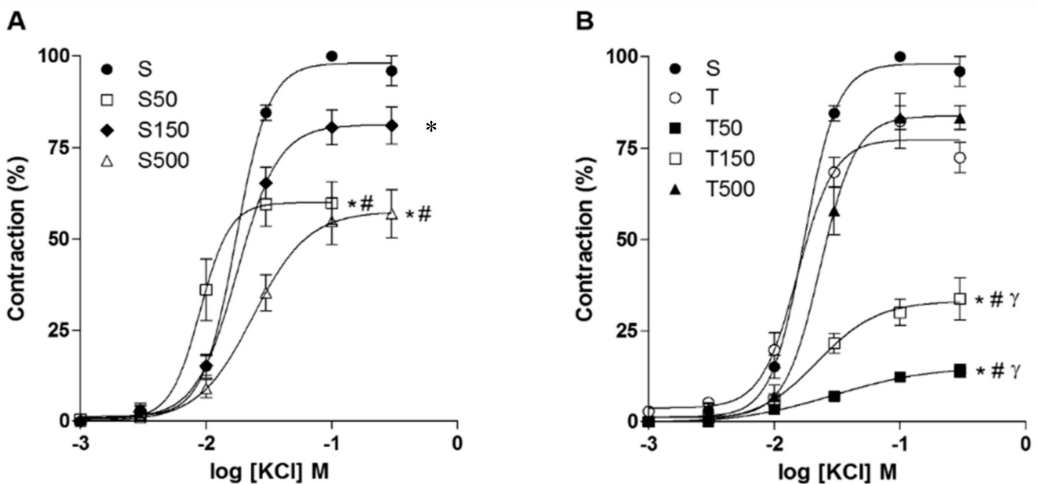

Figure 1. Cumulative concentration-response curves to $\mathrm{KCl}$ in S, S50, S150, S500 (A), and T, T50, T150, and T500 groups (B) in rat ileum. Symbols and the bars represent the mean and e.p.m., respectively $(n=3-5)$.Two-way ANOVA followed by Tukey's post-test: * $p<0.05$ (S vs. S50, S500, T50, and T150), $\# p<0.05$ (S50 and S500 vs. S150; T vs. T50 and T150), $\gamma p<0.05$ (T50 and T150 vs. T500).

Table 1. Values of $E_{\max }(\%)$ and $\mathrm{pEC}_{50}$ of $\mathrm{KCl}$ in the S, S50, S150, S500, T, T50, T150, and T500 groups in rat ileum.

\begin{tabular}{ccc}
\hline $\mathbf{K C l}(\mathbf{M})$ & $\boldsymbol{E}_{\max }(\mathbf{\%})$ & $\mathrm{pEC}_{\mathbf{5 0}}$ \\
\hline $\mathrm{S}$ & 100.0 & $1.76 \pm 0.02$ \\
$\mathrm{~S} 50$ & $59.7 \pm 5.8^{* \#}$ & $2.04 \pm 0.04^{*}$ \\
$\mathrm{~S} 150$ & $71.6 \pm 7.1 *$ & $1.76 \pm 0.04$ \\
$\mathrm{~S} 500$ & $51.3 \pm 4.5^{* \#}$ & $1.63 \pm 0.02$ \\
$\mathrm{~T}$ & $82.4 \pm 7.5$ & $1.78 \pm 0.06$ \\
$\mathrm{~T} 50$ & $14.0 \pm 1.8^{* \# \gamma}$ & $1.58 \pm 0.09$ \\
$\mathrm{~T} 150$ & $33.7 \pm 5.7 * \# \gamma$ & $1.65 \pm 0.07$ \\
$\mathrm{~T} 500$ & $83.3 \pm 3.1$ & $1.64 \pm 0.04$ \\
\hline
\end{tabular}

Data are expressed as the mean and e.p.m $(n=3-5)$. One-way ANOVA followed by Tukey's post-test: $E_{\max }:{ }^{*} p<0.05$ (S vs. S50, S500, T50, and T150), ${ }^{\#} p<0.05$ (S50 and S500 vs. S150; T vs. T50 and T150), ${ }^{\gamma} p<0.05$ (T50 and T150 vs. T500); $\mathrm{pEC}_{50}:{ }^{*} p<0.05$ (S50 vs. S, S150 and S500).

\subsection{Pharmacomechanical Coupling Contractile Reactivity Measurement}

Cumulative concentration-response curves to $\mathrm{CCh}\left(10^{-9}\right.$ to $\left.10^{-4} \mathrm{M}\right)(n=3-5)$ were attenuated, with the reduction of $E_{\max }$, by supplementation with S. platensis at doses of 150 and $500 \mathrm{mg} / \mathrm{kg}$, but not at $50 \mathrm{mg} / \mathrm{kg}(p<0.05)$. The strength exercise also reduced the efficacy of CCh, as well as its combination with supplementation at all doses $(p<0.05)$. Regarding the $\mathrm{pEC}_{50}$ values, only $500 \mathrm{mg} / \mathrm{kg}$ increased the potency of $\mathrm{CCh}$, without association with training $(p<0.05)$ (Figure 2, Table 2).

Table 2. Values of $E_{\max }(\%)$ and $\mathrm{pEC}_{50}$ of $\mathrm{KCl}$ in the C, C50, C150, C500, T, T50, T150, and T500 groups in rat ileum.

\begin{tabular}{ccc}
\hline CCh (M) & $E_{\max }(\mathbf{\%})$ & pEC $_{\mathbf{5 0}}$ \\
\hline S & 100.0 & $5.99 \pm 0.05$ \\
S50 & $92.5 \pm 2.6$ & $6.19 \pm 0.11$ \\
S150 & $30.0 \pm 0.9^{*}$ & $6.26 \pm 0.10$ \\
S500 & $53.3 \pm 3.8^{*} \#$ & $6.43 \pm 0.15 *$ \\
T & $57.1 \pm 5.8^{*}$ & $6.44 \pm 0.14$ \\
T50 & $33.3 \pm 2.0 * \#$ & $6.35 \pm 0.18$ \\
T150 & $56.6 \pm 3.9 *$ & $6.38 \pm 0.20$ \\
T500 & $43.5 \pm 4.5 *$ & $6.07 \pm 0.18$
\end{tabular}

Data are expressed as the mean and e.p.m $(n=3-5)$. Two-way ANOVA followed by Bonferroni's post-test: $E_{\max }$ : ${ }^{*} p<0.05$ (S or S50 vs. S150, and S500; S vs. T, T50, T150 and T500), ${ }^{*} p<0.05$ (S150 vs. S500; T and T150 vs. T50); $\mathrm{pEC}_{50}:^{*} p<0.05$ (S vs. S500). 

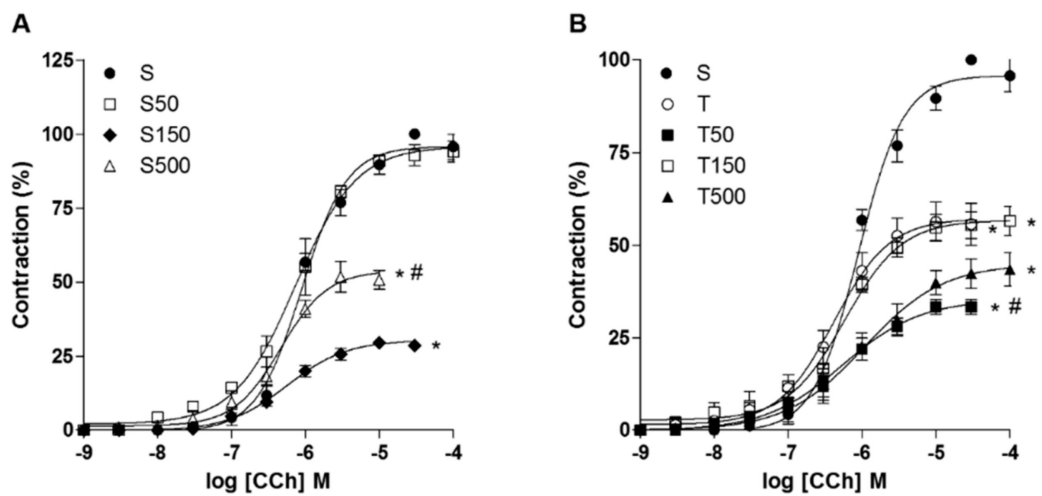

Figure 2. Cumulative concentration-response curves to CCh in S, S50, S150, and S500 (A), and T, T50, T150, and T500 groups (B) of rat ileum. Symbols and the bars represent the mean and e.p.m., respectively $(n=3-5)$. One-way ANOVA followed by Tukey's post-test: * $p<0.05$ (S or S50 vs. S150 and S500; $\mathrm{S}$ vs. T, T50, T150 and T500), ${ }^{\#} p<0.05$ (S150 vs. S500; T and T150 vs. T50).

\subsection{Lipid Peroxidation Assay}

The MDA concentration in rat ileum $(n=5)$ was decreased from $19.7 \pm 1.2(\mathrm{~S})$ to $12.8 \pm 1.0 \mu \mathrm{mol} / \mathrm{L}$ by supplementation with $S$. platensis only at $500 \mathrm{mg} / \mathrm{kg}(p<0.05)$, but did not differ in S50 $(17.9 \pm 0.0 \mu \mathrm{mol} / \mathrm{L})$ and $\mathrm{S} 150(15.8 \pm 1.0 \mu \mathrm{mol} / \mathrm{L})$. The strength training did not alter the MDA levels in ileum $18.0 \pm 2.0 \mu \mathrm{mol} / \mathrm{L}$, as well as its combination with the algae at $50 \mathrm{mg} / \mathrm{kg}(18.0 \pm 1.0 \mu \mathrm{mol} / \mathrm{L})$; however, the supplementation of exercised animals at 150 and $500 \mathrm{mg} / \mathrm{kg}$ reduced the MDA concentrations to $11.8 \pm 0.8$ and $6.8 \pm 0.6 \mu \mathrm{mol} / \mathrm{L}$ (Figure 3 ).

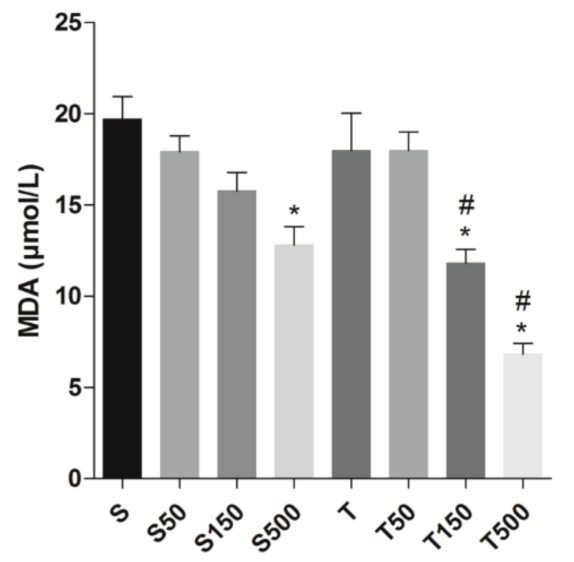

Figure 3. Concentration of MDA ( $\mu \mathrm{mol} / \mathrm{mL})$ of $\mathrm{S}, \mathrm{S} 50, \mathrm{~S} 150, \mathrm{~S} 500, \mathrm{~T}, \mathrm{~T} 50, \mathrm{~T} 150$, and T500 groups in rat ileum. Columns and vertical bars represent the mean \pm S.E.M., respectively $(n=5)$. Two-way ANOVA followed by Bonferroni's post-test: * $p<0.05$ (S vs. S500; T vs. T150 and T500); ${ }^{\#} p<0.05$ (T50 vs. T150 and T500).

\subsection{Antioxidant Assay}

The oxidation inhibition, based on DPPH concentration, in rat ileum $(n=5)$ from $\mathrm{S}$ group $(40.0 \pm 5.0 \%)$ was not altered by supplementation with algae at $50(42.0 \pm 4.0 \%)$ and $150 \mathrm{mg} / \mathrm{kg}$ $(44.0 \pm 3.0 \%)$; but was increased to $64.0 \pm 0.9 \%$ at $500 \mathrm{mg} / \mathrm{kg}$. The strength exercise did not alter this parameter $(49.0 \pm 5.0 \%)$, as well as its combination with S. platensis supplementation at $50 \mathrm{mg} / \mathrm{kg}$ $(49.0 \pm 5.0 \%)$; however, at $150(68.0 \pm 2.0 \%)$ and $500 \mathrm{mg} / \mathrm{kg}(82.0 \pm 2.0 \%)$, the supplementation associated with training increased the oxidation inhibition on rat ileum (Figure 4). 


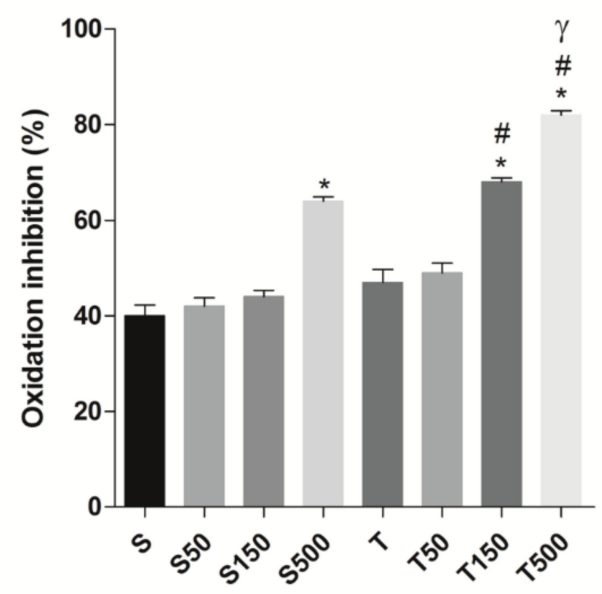

Figure 4. Oxidation inhibition (\%) in the S, S50, S150, S500, T, T50, T150, and T500 groups in rat ileum. Columns and vertical bars represent the mean \pm S.E.M. respectively $(n=5)$. Two-way ANOVA followed by Bonferroni's post-test: * $p<0.05$ (S vs. S500; T vs. T150 and T500); ${ }^{*} p<0.05$ (T50 vs. T150 and T500); $\gamma_{p}<0.05$ (T150 vs. T500).

\section{Discussion}

In this work, we investigated the modulation of contractile reactivity of rat ileum by food supplementation with the blue algae Spirulina platensis, strength exercise and the association of supplementation with training, as well as its effects on the balance between oxidative stress and antioxidant defenses. As a result, we demonstrated that algae supplementation reduces the maximum amplitude of the intestinal contractile response to both electro- and pharmaco-mechanical stimulation, in sedentary animals or those submitted to strength exercise. However, the physical exercise alone negatively modifies only the reactivity to pharmacomechanical coupling of contraction. Additionally, although the exercise program did not promote alterations in the overall balance between reactive oxygen species (ROS) production and antioxidant defenses in the intestine, algae supplementation reduced oxidative stress as well as improved intestinal antioxidant defenses in both sedentary and trained rats.

The importance of natural products as a therapeutic choice for numerous diseases has been already described. Among these natural products, the aquatic algae Spirulina platensis is highlighted, having presented some pharmacological activities, such as hypoglycemic, anti-inflammatory and antioxidant, contributing to the prevention and treatment of cardiovascular, metabolic, and inflammatory diseases [12]. Indeed, studies with animals and humans have demonstrated that the supplementation with the algae prevents oxidative stress, as well as the endothelial dysfunction [17,18].

We postulated that oral supplementation with S. platensis could alter, in some way, the intestinal contractile reactivity, which modifies the gastrointestinal functioning. For this, $\mathrm{CCh}$, a muscarinic agonist, was used as pharmacomechanical contractile agent mimicking the acetylcholine (ACh) effects, as it is released from myenteric autonomic nerves to regulate intestinal smooth muscle motility $[19,20]$. This agonist binds to $M_{3}$ receptors, which leads to $G_{q / 11}$ protein pathway activation, and stimulation of phospholipase $\mathrm{C}$, resulting on $\mathrm{Ca}^{2+}$ influx and release from sarcoplasmic reticulum and, then, intestinal muscle contraction [21-24]. Additionally, to simulate the electric pacemaker of interstitial cells of Cajal located at the boundaries and in the substance of the inner smooth muscle layer, from which they spread to the outer longitudinal smooth muscle layer, $\mathrm{KCl}$ was employed, as it depolarizes the cell membrane, resulting in $\mathrm{Ca}^{2+}$ influx by voltage-sensitive $\mathrm{Ca}^{2+}$ channels $(\mathrm{Ca}$ ) $[25,26]$.

Our data showed that $S$. platensis, at 50,150 , and $500 \mathrm{mg} / \mathrm{kg}$, reduced the ileum reactivity to $\mathrm{KCl}$ (Figure 1A, Table 1). On the other hand, supplementation reduced, in a dose-dependent manner, the ileum reactivity for CCh at 50 and $150 \mathrm{mg} / \mathrm{kg}$, however, at $500 \mathrm{mg} / \mathrm{kg}$, this effect was not observed (Figure 2A, Table 2). These data indicate that algae supplementation reduces the $\mathrm{Ca}^{2+}$ influx through $\mathrm{Ca}_{\mathrm{V}}$ on smooth muscle or on myenteric nerves, which additionally could reduce the release of 
neurotransmitters, as ACh, explaining the reduced efficacy of the agonist in the animals supplemented with the algae. Furthermore, the contractile potency of $\mathrm{KCl}$ and $\mathrm{CCh}$ was increased, despite the reduced efficacy, at 50 and $500 \mathrm{mg} / \mathrm{kg}$, respectively, since its $\mathrm{pEC}_{50}$ was increased at these doses. Since the increased potency of stimulation is associated by an augment in the number of receptors on cell membrane [27], this find can be explained by an increase expression of $\mathrm{Ca}_{\mathrm{V}}$ and $\mathrm{M}_{3}$ (or a combination of both) promoted by the algae, probably as a compensatory mechanism for the reduced ACh release. However, the elucidation of the obtained results requires additional research; such statement can be confirmed by the examination of ACh levels in the ileum.

Physical exercise is characterized by removing the organism from homeostasis, due to the increased energy expenditure by the musculature, leading to physiological responses [28]. During exercise, the blood flow is diverted in greater quantities for the musculature and skin to oxygenate these tissues, leading to the splanchnic ischemia-reperfusion process. Because of this, these processes can generate reactive oxygen species, which disrupts normal cellular functioning due to the oxidative stress, which alters the function of macromolecules [29]. However, just as reactive oxygen species are generated, there is the antioxidant defense that fights these free radicals, and the body returns to homeostasis.

Some studies which have focused on the effects of strength training on organ functioning, especially vascular beds, have demonstrated vascular function improvement by strength exercise [30-33]. In addition, these studies showed a reduction on vascular reactivity by this modality of exercise [34]. However, concerning the gastrointestinal tract, little is known about the effects of physical exercise. The exercise promotes ischemia and motor changes in the intestine and intestinal mucosa [35], and shows that swimming as an acute and chronic aerobic exercise reduces ileum reactivity to both $\mathrm{KCl}$ and CCh $[15,16]$; however the influence of anaerobic exercise of resistance was not evaluated so far.

Then, we evaluated the influence of strength exercise on ileum reactivity and the combination with S. platensis supplementation, in view of a possible potentiation on the beneficial effects when associated; however, initially we confirmed the effectiveness of exercise by observing an increase in the time to perform the exercise sessions, and that the program of strength exercise with progressive loads does not promote an overtraining [36], observing that the activity of lactate dehydrogenase (LDH) and creatine kinase (CK) were not increased (data not showed).

We observed that the training decreased the reactivity of rat ileum to $\mathrm{CCh}$, but not to $\mathrm{KCl}$, indicating a preferential effect on $\mathrm{ACh}$ release than on $\mathrm{Ca}_{\mathrm{V}}$ expression or activity. Additionally, when combined with the algae, there was a potentiation on the reduction on contractile reactivity, since this effect was observed at lower doses than occurred on sedentary rats (Figures 1 and 2, Tables 1 and 2), for both contractile agents. Therefore, these data reinforce a potentiation promoted by the algae on the effects of strength exercise on rat ileum contractility.

Despite these hypotheses, the data obtained do not allow an in-depth analysis of the mechanisms involved in these alterations, and additional studies are necessary to mechanistically elucidate these findings.

Studies of acute and chronic swimming exercise have shown that acute exercise does not promote oxidative stress in rat ileum. Furthermore, there is an increase after four weeks of exercise, but after six to eight weeks, oxidative stress is reduced, showing that the body underwent physiological changes to adapt to exercise and returned to homeostasis $[15,16]$. However, regarding the strength exercise, there are not data showing its effect on the balance oxidative stress and antioxidant defenses.

Literature data shows that $S$. platensis presents antioxidant activity due to the pigment phycocyanin, a very stable molecule and free radical scavenger [37], beyond its inhibitory effect on the production of superoxide anion [38,39]. In addition, other constituents contribute to the antioxidant benefits of the algae, as carotenoids, that regulate superoxide dismutase (SOD) and catalase (CAT), as well as block free radicals by chelation of metal ions, preventing lipid peroxidation; and vitamins $B$ and $E$, that act as antioxidants via capture of radicals and metal chelating agents [40]. 
Our data showed that food supplementation with the algae, at the higher dose $(500 \mathrm{mg} / \mathrm{kg})$, decreased the level of oxidative stress in rat ileum, since there was a reduction in the MDA concentration measured; an oxidative damage marker formed by oxidation of lipid of cell membrane [41]. Differently, the strength training did not alter the formation of ROS, but the association of exercise and $S$. platensis supplementation reduced this parameter at 150 and $500 \mathrm{mg} / \mathrm{kg}$ (Figure 3), indicating that this combination promotes beneficial effect regarding the prevention of cell oxidative damage. Confirming these data, it was observed that both supplementation $(500 \mathrm{mg} / \mathrm{kg})$ and the association, at the same doses, improved the antioxidant capacity of rat ileum (Figure 4).

Taken together, these data point to a possible beneficial effect of food supplementation with $S$. platensis, as well as its association with strength training - this is preliminary data that needs further testing, including in humans to confirm possible effects such the reduction of oxidative damage in the intestine, which may contribute for a better intestinal functioning, especially during exposure to stress.

\section{Material and Methods}

\subsection{Animals}

Wistar rats (Rattus norvegicus), initially 2-months-old, weighing 200-300 g, were obtained from animal production unit of UFPB. The animals were kept under restricted food control with balanced diet (Labina ${ }^{\circledR}$, São Paulo, Brazil), to avoid large differences in body weight and density, and had access to water ad libitum. They were maintained in rooms at $21 \pm 1{ }^{\circ} \mathrm{C}$ and submitted to a $12 \mathrm{~h}$ light-dark cycle (light on from 6 to $18 \mathrm{~h}$ ). Forty-eight hours after the last exercise session, the animals were fasted for $18 \mathrm{~h}$ (receiving only water ad libitum during this period), to avoid the influence of substances released during digestion, and then euthanized by cervical dislocation followed by cervical vessels section to proceed with the experimental analysis.

All experimental procedures were performed following the principles of animal care of the Guidelines for the ethical use of animals in applied etiology studies [42] and previously approved by UFPB Ethics Committee on Animal Use (Protocol/CEUA 0511/13).

\subsection{Drugs}

Calcium chloride bihydrate $\left(\mathrm{CaCl}_{2} \cdot 2 \mathrm{H}_{2} \mathrm{O}\right)$, magnesium chloride hexahydrate $\left(\mathrm{MgCl}_{2} \cdot 6 \mathrm{H}_{2} \mathrm{O}\right)$, and glucose $\left(\mathrm{C}_{6} \mathrm{H}_{12} \mathrm{O}_{6}\right)$ were purchased from Vetec (Darmstadt, Germany). Sodium bicarbonate $\left(\mathrm{NaHCO}_{3}\right)$ was purchased from Fmaia (Belo Horizonte, Brazil). Sodium chloride $(\mathrm{NaCl})$ and potassium chloride $(\mathrm{KCl})$ were purchased from Química Moderna (São Paulo, Brazil). Monosodium dihydrogen orthophosphate $\left(\mathrm{NaH}_{2} \mathrm{PO}_{4}\right)$, sodium hydroxide $(\mathrm{NaOH})$ and hydrochloric acid $(\mathrm{HCl})$ were purchased from Nuclear (Brazil). These substances were employed in the physiological Tyrode solution for functional experiments. Carbamylcholine hydrochloride (CCh) was purchased from Merck (Darmstadt, Germany). Thiobarbituric acid, tetramethoxypropane and perchloric acid were purchased from Sigma-Aldrich (St. Louis, MO, USA). Carbogen mixture $\left(95 \% \mathrm{O}_{2}\right.$ and $\left.5 \% \mathrm{CO}_{2}\right)$ was obtained from White Martins (Danbury, CT, USA).

\subsection{Spirulina Platensis}

S. platensis was obtained as powder from the Dongtai Top Bio Engineering Co., Ltd. (Nanjing, China) (lot 20130320). A sample was analyzed for quality control by Farma Nostra laboratory (Anápolis, Goiás, Brazil) (Lot 1308771A) and handled by Dilecta pharmacy (João Pessoa, Paraíba, Brazil) (lot 20121025).

\subsection{Experimental Protocol}

Animals were divided into eight groups (five animals in each): Sedentary (S), trained (T), sedentary and supplemented with S. platensis at 50 (S50), 150 (S150), and $500 \mathrm{mg} / \mathrm{kg}$ (S500), and a combination of training and supplementation at 50 (T50), 150 (T150), and $500 \mathrm{mg} / \mathrm{kg}$ (T500). 
Animals of trained groups were submitted to a specific program of water jumping; for this, water was heated to around $32{ }^{\circ} \mathrm{C}$ [43]. The week of adaptation was consisted of three alternating sessions of exercise (1st day: 2 sets $\times 5$ jumps, 2 nd day: 4 sets $\times 5$ jumps, and 3rd day: 4 sets $\times 5$ jumps), with an overload of $50 \%$ of the body weight. The strength training program consisted of 4 sets of 12 repetitions, with a 30 second interval between sets; a progressive load was adjusted according to the animal weight, being 50\% (1st and 2nd week), 60\% (3th and 4 th week), and 80\% of body weight (5th to 8th week), anchored in the trunk of the animals by a vest. After $48 \mathrm{~h}$ from the end of the training, the animals were euthanized and the ileum was isolated (Figure 5).

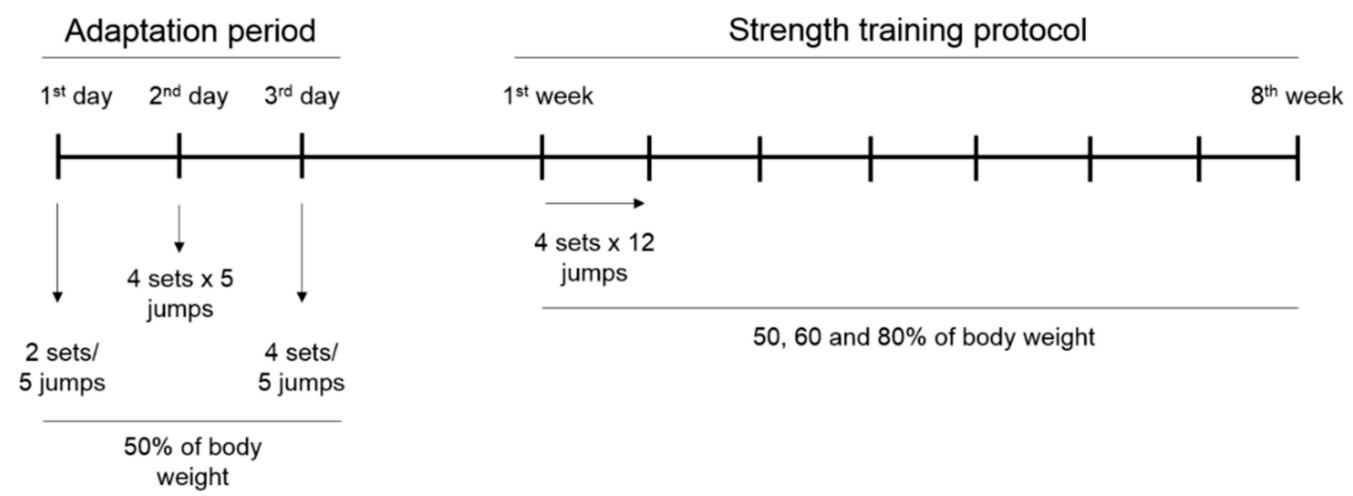

Figure 5. Strength training program. Adaptation period: 1-3 days; and strength training protocol: 1-8 weeks.

For supplementation with $S$. platensis, the algae was dissolved in saline solution and orally administrated by gavage (volume: $2.5 \mathrm{~mL} /$ animal) along 8 weeks [44]. For trained + supplemented animals, administration was performed $30 \mathrm{~min}$ before exercise session and sedentary animals received saline solution [45].

\subsection{Contractile Reactivity Measurement}

Animals were euthanized. The ileum was immediately removed, cleaned of fat and connective tissue, and immersed in physiological solution at room temperature and bubbled with carbogen mixture. To register isotonic contractions, ileum segments $(2-3 \mathrm{~cm})$ were suspended by cotton yarn in organ bath $(5 \mathrm{~mL})$ and recorded on smoked drum through levers coupled to kymographs (DTF) under resting tension of $1.0 \mathrm{~g}$ at $37^{\circ} \mathrm{C}$ [46]. The organ baths were warmed by a thermostatic pump Polystat 12,002 Cole-Palmer (Vernon Hills) and bathed by a Tyrode solution (pH 7.4) with the following composition (in mM): $\mathrm{NaCl}$ (150.0), $\mathrm{KCl}$ (2.7), $\mathrm{CaCl}_{2}$ (1.8), $\mathrm{MgCl}_{2}$ (2.0), $\mathrm{NaHCO}_{3}$ (12.0), $\mathrm{NaH}_{2} \mathrm{PO}_{4}$ (0.4), and D-glucose (5.5). After $30 \mathrm{~min}$ of stabilization period, an isotonic contraction was induced with $\mathrm{KCl} 30 \mathrm{mM}$, to verify the functionality of the organ, and $15 \mathrm{~min}$ after two similar cumulative concentration-response curves to $\mathrm{KCl}$ or $\mathrm{CCh}$ were obtained, as electro- and pharmaco-mechanical coupling contractile agents. The reactivity of ileum to that agents was assessed and compared between groups based on the values of maximum effect $\left(E_{\max }\right)$ and negative logarithm of the concentration of contractile agents producing $50 \%$ of its maximal effect.

\subsection{Lipid Peroxidation Assay}

Lipid peroxidation in ileum was determined measuring the chromogenic product of 2-thiobarbituric acid (TBA) reaction with malondialdehyde (MDA), which is one of the products formed because of membrane lipid peroxidation [47]. Ileum segments from each animal were homogenized with $\mathrm{KCl}(1: 1)$ and $250 \mu \mathrm{L}$ of tissue homogenate were incubated at $37^{\circ} \mathrm{C}$ for $60 \mathrm{~min}$. Then, the mixture was precipitated with $35 \%$ perchloric acid and centrifuged at $1.207 \mathrm{~g}$ for $20 \mathrm{~min}$ at $4{ }^{\circ} \mathrm{C}$. The supernatant was transferred to Eppendorf ${ }^{\circledR}$ tubes and $400 \mu \mathrm{L}$ of TBA $0.6 \%$ were added and incubated at $95-100{ }^{\circ} \mathrm{C}$ 
for $1 \mathrm{~h}$. After cooling, the samples were read in spectrophotometer at wavelength of $532 \mathrm{~nm}$. The results were expressed in $\mu \mathrm{mol} / \mathrm{L}$ per gram of dry tissue.

\subsection{Antioxidant Assay}

Ileum segments from each animal were homogenized with $\mathrm{KCl}(1: 1)$, centrifuged at $1.198 \times g$ for $10 \mathrm{~min}$ and $250 \mu \mathrm{L}$ of supernatant were incubated at $37^{\circ} \mathrm{C}$ for $60 \mathrm{~min}$. Then, $100 \mu \mathrm{L}$ of the tissue was added in an Eppendorf ${ }^{\circledR}$ tube with $2 \mathrm{~mL}$ of 2,2-diphenyl-1-picrylhydrazyl (DPPH) solution $(1.25 \mathrm{~mL}$ DPPH dissolved in $100 \mathrm{~mL}$ ethanol). The tubes were vortexed and allowed to stand for $30 \mathrm{~min}$. They were centrifuged at $7.489 \times g$ at $20^{\circ} \mathrm{C}$ for $15 \mathrm{~min}$. Then, the samples were read in spectrophotometer at a wavelength of $515 \mathrm{~nm}$.

The results were expressed as a percentage of oxidation inhibition, following the equation:

$$
\mathrm{AOA}=100-\left[(\mathrm{DPPH}-\mathrm{R})_{\mathrm{S}} /(\mathrm{DPPH}-\mathrm{R})_{\mathrm{W}} \times 100\right]
$$

where (DPPH-R $)_{S}$ and (DPPH-R $)_{W}$ correspond to the concentration of DPPH- remaining after $30 \mathrm{~min}$, measured in the sample (S) and white $(\mathrm{W})$ prepared with distilled water [48].

\subsection{Statistical Analysis}

Data were expressed as mean \pm standard error of mean (S.E.M.). Cumulative concentrationresponse curves were fitted and $\mathrm{pEC}_{50}$ values were obtained by non-linear regression [28]. Multiple comparisons were performed by one- or two-way ANOVA followed by Tukey or Bonferroni's post-test. The differences were considered significant when $p<0.05$. All data were analyzed using GraphPad Prism ${ }^{\circledR}$ software version 5.01 (GraphPad Software Inc., California, LA, USA).

\section{Conclusions}

An experimental model of smooth muscle is important for studying its functioning and new pharmacological and non-pharmacological strategies for the treatment of disorders, such as those affecting the intestinal tract. Our data point to a possible beneficial effect of food supplementation with S. platensis, as well as its association with strength training on oxidative stress and contractile reactivity. This is preliminary data needs further testing, including in humans, to confirm possible effects of the reduction of oxidative damage in the intestine, which may contribute for a better intestinal functioning, especially during exposure to stress.

Author Contributions: L.C.C.A. performed the experiments and performed the original draft of manuscript; A.F.B. participated in the strength training protocol an biochemical assays acquisition; I.L.L.S. performed part of the intestinal contractile reactivity experiments and participated in the editing and review of manuscript; P.B.F. executed part of contractile reactivity experiments; L.H.C.V. performed part of the strength training protocol, intestinal contractile reactivity experiments and reviewed and edited the original draft; A.S.S. assisted with the analysis of lipid peroxidation and antioxidant assay experiments and B.A.S. conceptualized the work, assisted with the data analysis and discussed the results. All authors have read and agreed to the published version of the manuscript.

Funding: This research was funded by Conselho Nacional de desenvolvimento Científico e Tecnológico (CNPq), grant number 433232/2016-1.

Acknowledgments: The authors thank Universidade Federal da Paraíba (UFPB) and Graduate Program in Cellular and Molecular Biology for experimental support, and José Crispim Duarte and Luís C. Silva for providing technical assistance. Coordenação de Aperfeiçoamento de Pessoal de Nível Superior (Capes) and Conselho Nacional de Desenvolvimento Científico e Tecnológico(CNPq) supported this research.

Conflicts of Interest: The authors declare no conflict of interest. 


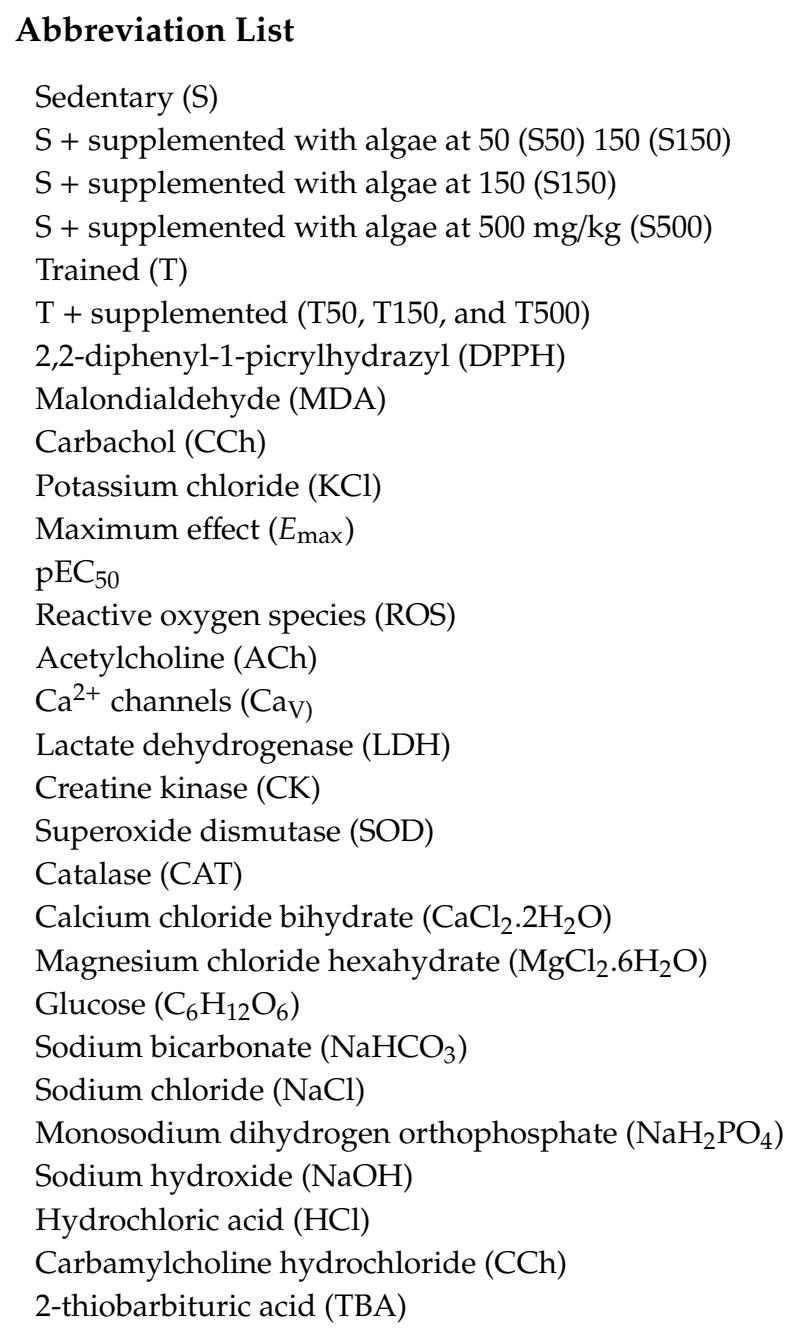

\section{References}

1. Newman, D.J.; Cragg, G.M.; Snader, K.M. Natural products as sources of new drugs over the period 1981-2002. J. Nat. Prod. 2003, 66, 1022-1037. [CrossRef] [PubMed]

2. Petrovska, B.B. Historical review of medicinal plants' usage. Pharmacogn. Rev. 2012, 6, 1-5. [CrossRef] [PubMed]

3. Pan, S.Y.; Litscher, G.; Gao, S.H.; Shou, S.F.; Yu, Z.L.; Chen, H.Q.; Zhang, S.F.; Tang, M.K.; Sun, J.N.; Ko, K.M. Historical perspective of traditional indigenous medical practices: The current renaissance and conservation of herbal resources. J. Evid. Based Complementary Altern. Med. 2014. [CrossRef] [PubMed]

4. Riccioni, G.; D'orazio, N.; Franceschelli, S.; Speranza, L. Marine carotenoids and cardiovascular risk markers. Mar. Drugs 2011, 9, 1166-1175. [CrossRef]

5. Blunt, J.W.; Copp, B.R.; Keyzers, R.A.; Munro, M.H.G.; Prinsep, M.R. Marine natural products. Nat. Prod. Rep. 2012, 29, 144-222. [CrossRef]

6. Yamazaki, D.A.; Sumilat, S.; Kanno, S.; Ukai, K.; Rotinsulu, H.; Wewengkang, D.S.; Ishikawa, M.; Mangindaan, R.E.P.; Namikoshi, M. A polybromodiphenyl ether from an Indonesian marine sponge Lamellodysidea herbacea and its chemical derivates inhibit protein tyrosine phosphatase 1B, an important target for diabetes treatment. J. Nat. Med. 2013, 67, 730-735. [CrossRef]

7. Ciferri, O. Spirulina, the edible microorganism. Microbio.l Rev. 1983, 47, 551-578. [CrossRef]

8. Riss, J.; Decorde, K.; Sutra, T.; Delage, M.; Baccou, J.C.; Jouy, N.; Brune, J.P.; Oreal, H.; Cristol, J.P.; Rouanet, J.M. Phycobiliprotein Cphycocyanin from Spirulina platensis is powerfully responsible for reducing oxidative stress and NADPH oxidase expression induced by an atherogenic diet in hamsters. J. Agric. Food Chem. 2007, 55, 7962-7967. [CrossRef] 
9. Park, H.J.; Lee, Y.J.; Ryu, H.Q.; Kim, M.H.; Chung, H.W.; Kim, W.Y. A randomized double-blind, placebo-controlled study to establish the the effects os Spirilina in elderly Koreans. Ann. Nutr. Metab. 2008, 52, 322-328. [CrossRef]

10. Ku, C.S.; Pham, T.X.; Park, Y.; Kim, B.; Shin, M.; Kang, I.; Lee, J. Edible blue-green algae reduce the production of pro-inflammatory cytokines by inhibiting NF-kB pathway in macrophages and splenocytes. Biochem. Biophys. Acta 2013, 1830, 2981-2989. [CrossRef]

11. Brito, A.F.; Silva, A.S.; Souza, A.A.; Ferreira, P.B.; Souza, I.L.L.; Araujo, L.C.C.; Félix, G.S.; Sampaio, R.S.; Silva, M.C.C.; Tavares, R.L.; et al. Aortic Response to Strength Training and Spirulina platensis Dependent on Nitric Oxide and Antioxidants. Front Physiol. 2018, 9, 1522. [CrossRef] [PubMed]

12. Wang, Y.; Wisloff, U.; Kemi, O.J. Animal models in the study of exercise-induced. Physiol. Res. 2010, 59, 633-644. [PubMed]

13. Abdel-Daim, M.M.; Frouk, S.M.; Madkour, F.F.; Azab, S.S. Anti-inflammatory and immunomodulatory effects of Spirulina platensis in comparison to Dunaliella salina in acetic acid-induced rat experimental colitis. J. Immunopharmacol. Immunotoxicol. 2015, 37, 126-139. [CrossRef] [PubMed]

14. Ma, H.; Xiong, H.; Zhu, X.; Ji, C.; Xue, J.; Li, R.; Ge, B.; Cui, H. Polysaccharide from Spirulina platensis ameliorates diphenoxylate-induced constipation symptoms in mice. Int. J. Biol. Macromol. 2019, 133, 1090-1101. [CrossRef] [PubMed]

15. Araujo, L.C.C.; Souza, I.L.L.; Vasconcelos, L.H.C.; Brito, A.F.; Queiroga, F.R.; Silva, A.S.; Silva, P.M.; Cavalcante, F.A.; Silva, B.A. Chronic aerobic swimming exercise promotes functional and morphological changes in rat ileum. Biosci Rep 2015, 35, 259. [CrossRef]

16. Araujo, L.C.C.; Souza, I.L.L.; Vasconcelos, L.H.C.; Brito, A.F.; Queiroga, F.R.; Silva, A.S.; Silva, P.M.; Cavalcante, F.A.; Silva, B.A. Acute aerobic swimming exercise induces distinct effects in the contractile reactivity of rat ileum to $\mathrm{KCl}$ and Carbachol. Front Physiol. 2016, 7, 103. [CrossRef]

17. Huang, Z.X.; Mei, X.T.; Xu, D.H.; Xu, S.B.; Lv, J.Y. Protective effects of polysaccharide of Spirulina platensis and Sargassum thunbeergii on vascular of alloxan induced diabetic rats. Zhongguo Zhong Yao Za Zhi 2005, 30, 211-215.

18. Wu, H.E.; Chen, T.F.; Yin, X.; Zheng, W.J. Spectrometric characteristics and underlying mechanisms of protective effects of selenium on Spirulina platensis against oxidative stress. Guang Pu Xue Yu Guang Pu Fen Xi 2012, 32, 749-754.

19. Furness, J.B.; Young, H.M.; Pompolo, S.; Bornstein, J.C.; Kunze, W.A.A.; McConalogue, K. Plurichemical transmission and chemical coding of neurons in the digestive tract. Gastroenterology 1995, 108, 554-563. [CrossRef]

20. Bornstein, J.C.; Costa, M.; Grider, J.R. Enteric motor and interneuronal circuits controlling motility. Neurogastroenterol. Motil 2004, 16, 34-38. [CrossRef]

21. Reuter, H. Properties of two in ward membrane currents in the heart. Annu. Rev. Physiol. 1979, 41, 413-424. [CrossRef] [PubMed]

22. Tsien, R.W. Calcium channels in excitable cell membranes. Annu. Rev. Physiol. 1983, 45, 341-358. [CrossRef] [PubMed]

23. Bers, D.M. Cardiac excitation-contraction coupling. Nature 2002, 415, 198-205. [CrossRef]

24. Somlyo, A.V.; Somlyo, A.P. Electromechanical and pharmacomechanical coupling in vascular smooth muscle. J. Pharmacol. Exp. Ther. 1968, 159, 129-145. [PubMed]

25. Tse, G.; Lai, E.T.; Yeo, J.M.; Tse, V.; Wong, S.H. Mechanisms of Electrical Activation and Conduction in the Gastrointestinal System: Lessons from Cardiac Electrophysiology. Front Physiol. 2016, 31, 182. [CrossRef] [PubMed]

26. Sanders, K.M.; Koh, S.D.; Ordog, T.; Ward, S.M. Ionic conductances involved in generation and propagation of electrical slow waves in phasic gastrointestinal muscles. Neurogastroenterol. Motil. 2004, 16, 100-105. [CrossRef] [PubMed]

27. Neubig, R.R.; Spedding, M.; Kenakin, T.; Christopoulos, A. International Union of Pharmacology Committee on Receptor Nomenclature and Drug Classification. XXXVIII. Update on terms and symbols in quantitative pharmacology. Pharmacol. Rev. 2003, 55, 597-606. [CrossRef]

28. Mcardle, W.D.; Katch, F.J.; Katch, V.L. Fisiologia do Exercício: Energia, nutrição e desempenho humano. Traduzido po Giuseppe Taranto. Rio de Janeiro; LWW: Philadelphia, PA, USA, 2016. 
29. Otte, J.; Oostveen, E.; Geelkerken, R.H.; Groeneveld, A.B.J.; Kolkman, J.J. Exercise induces gastric ischemia in healthy volunteers: A tonometry study. Eur. J. Appl. Physiol. 2001, 91, 866-871. [CrossRef]

30. Brito, A.F.; Alves, N.F.B.; Souza, A.A.; Goncalves, M.C.R.; Silva, A.S. Active intervals between sets of resistance exercises potentiate the magnitude of postexercise hypotension in elderly hypertensive women. J. Strength Cond. Res. 2011, 25, 3129-3136. [CrossRef]

31. Trinity, J.D.; Wray, D.W.; Witman, M.A.; Layec, G.; Barrett-O’Keefe, Z.; Ives, S.J.; Conklin, J.D.; Reese, V.; Richardson, R.S. Contribution of nitric oxide to brachial artery vasodilation during progressive handgrip exercise in the elderly. Am. J. Physiol. Regul. Integr. Comp. Physiol. 2013, 305, 893-899. [CrossRef]

32. Beck, D.T.; Martin, J.S.; Casey, D.P.; Braith, R.W. Exercise training improves endothelial function in resistance arteries of young prehypertensives. J. Hum. Hypertens. 2014, 28, 303-309. [CrossRef] [PubMed]

33. Choi, Y.; Akazawa, N.; Miyaki, A.; Ra, S.G.; Shiraki, H.; Ajisaka, R.; Maeda, S. Acute effect of high-intensity eccentric exercise on vascular endothelial function in young men. J. Strength Cond. Res. 2014, 14, 2279-2285. [CrossRef] [PubMed]

34. Araújo, A.J.S.; Santos, A.C.V.; Souza, K.S.; Aires, M.B.; Santana-Filho, V.J.; Fioretto, E.T.; Mota, M.M.; Santos, M.R.B. Resistance training controls arterial blood pressure in rats with L-NAME-induced hypertension. Arq Bras Cardiol 2013, 100, 339-346. [CrossRef] [PubMed]

35. Ballabeni, B.; Barocelli, E.; Bertoni, S.; Impicciatore, M. Alterations of intestinal motor responsiveness in a model of mild mesenteric ischemia/reperfusion in rats. Life Sci. 2002, 71, 2025-2035. [CrossRef]

36. Smith, L.L. Tissue trauma: The underlying cause of overtraining syndrome? J. Strength Cond. Res. 2004, 18, 185-193. [CrossRef]

37. Bhat, V.B.; Madyastha, K.M. C-phycocyanin: A potent peroxyl radical scavenger in vivo and in vitro. Biochem. Biophys. Res. Commun. 2000, 275, 20-25. [CrossRef]

38. Mccarty, M.F. Clinical potential of Spirulina as a source of phycocyanobilin. J. Med. Food 2007, 10, 566-570. [CrossRef]

39. Kuddus, M.; Singh, P.; Thomas, G.; Al-Hazimi, A. Recent developments in production and biotechnological applications of C-phycocyanin. Biomed. Res. Int. 2013, 2013, 742-859. [CrossRef]

40. Cuvelier, M.E. Antioxidants. In Functional foods: An introductory course; Morais, R., Ed.; Universidade 611 Católica Portuguesa-Escola Superior de Biotecnologia: Porto, Portugal, 2001; pp. 95-105.

41. Del Rio, D.; Stewart, A.J.; Pellegrini, N. A review of recent studies on malondialdehyde as toxic molecule and biological marker of oxidative stress. Nutr. Metab. Cardiovasc. Dis. 2005, 15, 316-328. [CrossRef]

42. Sherwin, C.M.; Christiansen, S.B.; Duncan, I.J.; Erhard, H.W.; Lay, D.C., Jr.; Mench, J.A.; O'Connor, C.E.; Petherick, J.C. Guidelines for the ethical use of animals in applied animal behaviour research. Appl. Animal Behaviour. Sci. 2003, 81, 291-305. [CrossRef]

43. Marqueti, R.C.; Parizotto, N.A.; Chriguer, R.S.; Perez, S.E.; Selistre-de-Araujo, H.S. Androgenic-anabolic steroids associated with mechanical loading inhibit matrix metallopeptidase activity and affect the remodeling of the achiles tendon in rats. Am. J. Sports Med. 2006, 34, 1274-1280. [CrossRef] [PubMed]

44. Juarez-Oropeza, M.A.; Mascher, D.; Torres-Durán, P.V.; Farias, J.M.; Paredes-Carbajal, M.C. Effects of dietary Spirulina on vascular reactivity. J. Med. Food. 2009, 12, 15-20. [CrossRef] [PubMed]

45. Stefani, G.P.; Nunes, R.B.; Dornrlles, A.Z.; Alves, J.P.; Piva, M.O.; Domenico, M.D.; Rhoden, C.R.; Lago, P.D. Effects of creatine supplementation associated with resistance training on oxidative stress in different tissues of rats. J. Int. Soc. Sports Nutr. 2014, 11. [CrossRef] [PubMed]

46. Radenkovic, M.; Ivetic, V.; Popovic, M.; Mimica-Dukic, N.; Veljkovic, S. Neurophysiological effects of mistletoe (Viscum album L.) on isolated rat intestines. Phytother. Res. 2006, 20, 374-377. [CrossRef]

47. Winterbourn, C.C.; Gutteridge, J.M.; Halliwell, B. Doxorubicindependent lipid peroxidation at low partial pressures of O2. J. Free Radic. Biol. Med. 1985, 1, 43-49. [CrossRef]

48. Brand Williams, W.; Cuvelier, M.E.; Berset, C. Use of a free radical method to evaluate antioxidant activity. LWT-Food Sci. Technol. J. 1995, 28, 25-30. [CrossRef]

(C) 2020 by the authors. Licensee MDPI, Basel, Switzerland. This article is an open access article distributed under the terms and conditions of the Creative Commons Attribution (CC BY) license (http://creativecommons.org/licenses/by/4.0/). 